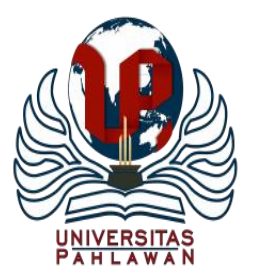

Edukatif : Jurnal Ilmu Pendidikan Vol 2 No 1 April 2020 Halm 101-112

EDUKATIF: JURNAL ILMU PENDIDIKAN

Research \& Learning in Education

https://edukatif.org/index.php/edukatif/index

\title{
THE CURRENT SITUATION AND PROSPECT OF STUDY QUALITY EVALUATION RESEARCH IN CHINA IN THE LAST 10 YEARS
}

\author{
Wu Aixia ${ }^{1}$, Zhou Ying ${ }^{2}$, Tommy Tanu Wijaya ${ }^{3}$ \\ Guangxi Normal University ${ }^{1,2,3}$ \\ e-mail : $\underline{838734477 @ q q . c o m}{ }^{1}, \underline{799936971 @ q q . \text { com }^{2}}, \underline{\text { tommytanu@ foxmail.com }^{3}}$
}

\begin{abstract}
Abstrak
Dengan melakukan observasi mendalam tentang reformasi pendidikan Cina, evaluasi kualitas pengajaran telah menjadi aspek penting dari reformasi pengajaran. Evaluasi kualitas pembelajaran siswa adalah bagian penting dari evaluasi pengajaran. Penelitian tentang hal itu akan membantu untuk meningkatkan kualitas pengajaran di China dan mempromosikan peningkatan keseluruhan dari moralitas siswa, kecerdasan, kesehatan badan dan keindahan. Oleh karena itu, penelitian ini mengambil 108 literatur yang berkaitan dengan studi evaluasi kualitas pembelajaran di Tiongkok sebagai penelitian. Metode pada penelitian ini menggunakan metode deskriptif analisis konten, melakukan analisis statistik pada jumlah literatur tahunan, distribusi Jurnal, status penulis, pengaruh jurnal, konten penelitian, dll., menganalisis situasi saat ini dan masalah yang ada dari studi evaluasi kualitas pembelajaran di China, dan mengedepankan perlunya pendalaman lebih lanjut. Atas dasar pertanyaan-pertanyaan ini, memungkinkan arah penelitian di masa depan.
\end{abstract}

Kata Kunci : Evaluasi kualitas pembelajaran, Metode analisis, Konten Analisis

\begin{abstract}
With the deepening of China's educational reform, the evaluation of teaching quality has become an important aspect of teaching reform.And the evaluation of students'learning quality is an important part of teaching evaluation. Research on it will help to improve the teaching quality of our country and promote the overall improvement of students' morality, intelligence, physical fitness and beauty.Therefore, this study takes 108 literatures related to the study of learning quality evaluation in China as the research object, uses content analysis method, carries out statistical analysis on the annual number of literatures, Journal distribution, author status, paper influence, research content, etc., analyzes the current situation and existing problems of the study of learning quality evaluation in China, and puts forward the need for further deepening. On the basis of these questions, possible future research directions are proposed.
\end{abstract}

Keywords: Learning quality evaluation, Analysis method, content analysis

@Edukatif: Jurnal Ilmu Pendidikan 2020

$\triangle$ Corresponding author :

Address : Yucai Road No 15, Guilin, China

Email : tommytanu@foxmail.com

ISSN 2656-8063 (Media Cetak)

Phone : 18677395150

ISSN 2656-8071 (Media Online) 
102 The Current Situation and Prospect of Study Quality Evaluation Research in China in The Last 10 Years Wu Aixia, Zhou Ying, Tommy Tanu Wijaya

\section{INTRODUCTION}

The evaluation of students' learning quality refers to the value judgment activities which take students' learning as the object (Pierce, Stacey, \& Barkatsas, 2007), take certain learning values as the guidance, take the realization of talent training goal as the core (Arumugham, 2019), and make objective and scientific evaluation and judgment on the effect, quality and development level of students' learning (Yi, Ying, \& Wijaya, 2019). At present, the study of learning quality evaluation is not only an important part of measuring students' learning effect (Wijaya, Dewi, Fauziah, \& Afrilianto, 2018; Yi et al., 2019), but also an important part of evaluating teachers' teaching effect (Wijaya, Ying, \& Purnama, 2020). However, in the face of diversified learning environment, rapid information change (Andini, Mulyani, Wijaya, \& Supriyati, 2018; Cunhua, Ying, Qunzhuang, \& Wijaya, 2019), the problem of learning quality evaluation has gradually revealed, which indirectly affects the quality of education In the past ten years, the research on learning quality evaluation has made rapid progress (Hutajulu, Wijaya, \& Hidayat, 2019), and gradually attracted the attention of researchers. The current situation, development and research of learning quality research in China have made some achievements (Fachrudin et al., 2019; Malinen, Savolainen, \& $\mathrm{Xu}, 2012$ ), but there is no systematic conclusion.

Therefore, this paper further analyzes the current situation and existing problems of learning quality evaluation research in China. It mainly reflects on the following three aspects: high- quality research papers need to be further improved (Kulsum, Hidayat, Wijaya, \& Kumala, 2019), researchers need to further strengthen their cooperative exploration, and research fields need to be further expanded (Sukaesih, Ridlo, \& Saptono, 2019). In this paper, the author puts forward some future research prospects, such as realizing the combination of qualitative and quantitative learning quality evaluation, broadening the research field of learning quality evaluation, strengthening the empirical research of learning quality evaluation, and paying attention to the diversity of learning quality evaluation.

\section{METHOD}

\section{research samples}

In CNKI advanced search column, select key words and title and input "learning quality evaluation", and input "2010-2019" in the year. A total of 110 relevant journals were retrieved. Then, articles on learning quality evaluation were screened out manually, and 108 were selected as research samples

\section{research method design}

Content analysis is an objective, systematic and quantitative method to describe the obvious content of communication (Miguel-Revilla, Martínez-Ferreira, \& Sánchez-Agustí, 2020; Tambychik \& Meerah, 2010). The specific operation steps are divided into six steps: determining the research topic, selecting the research analysis unit, taking research samples, developing research scale, applying the scale to analyze and classify, and drawing conclusions. Based on this method, this study analyzes 108 research literatures of learning quality evaluation. 
103 The Current Situation and Prospect of Study Quality Evaluation Research in China in The Last 10 Years Wu Aixia, Zhou Ying, Tommy Tanu Wijaya

The analysis dimension includes five aspects: annual quantity analysis of literature, journal distribution, author's situation, influence analysis of papers and research content analysis. In the analysis process, quantitative analysis and qualitative analysis are used.

\section{RESULTS AND DISCUSSION}

\section{Annual Quantitative Analysis of Literature}

The annual quantitative analysis of literatures has important statistical significance. From the annual quantitative distribution of literatures, we can understand the dynamic development process of a subject and judge its development trend. Fig. 1 is the annual quantitative distribution map of research literatures on learning quality evaluation.

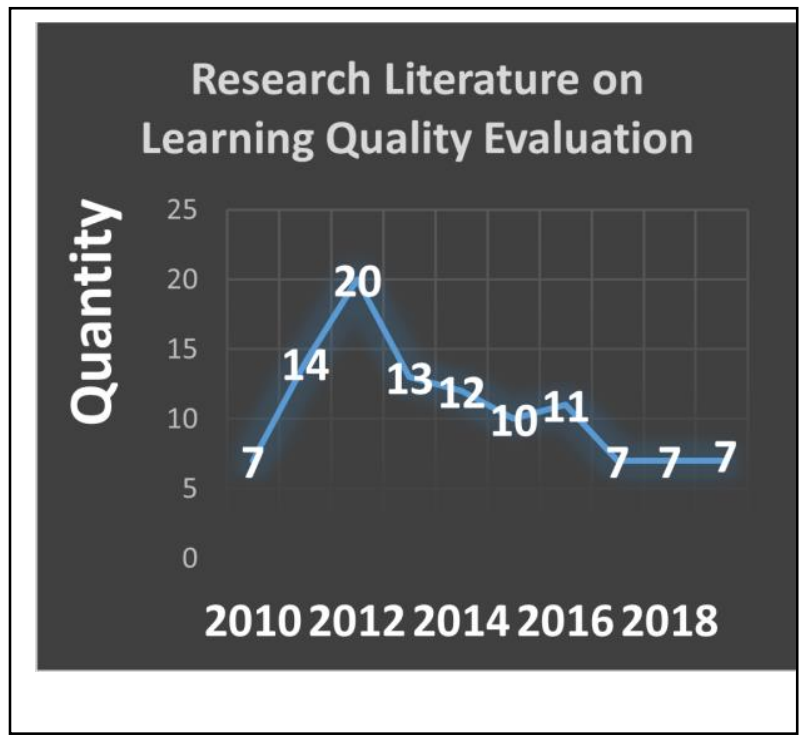

Fig. 1 Distribution of annual quantity of research literature on learning quality evaluation

According to Fig. 1, we can find that there are 7 papers in the minimum year and 20 papers in the maximum year, with an average of 11 papers per year. From 2010 to 2012, the number of papers published has increased year by year, reaching a peak (20 papers), and then declined. Among them, 2012 is the year in which the most research results were published. Among the related papers published in 2012, statistics found that 20 papers Fifteen of them are about the evaluation of the learning quality of Higher Vocational education. By consulting relevant documents, it is found that on August 30, September 29 and 30, 2011, three documents guiding the development of higher vocational education were issued successively, namely the Guiding Opinions of the Ministry of Education on Promoting the Harmonious Development of Secondary and Higher Vocational Education, the Guiding Opinions of the Ministry of Education on Promoting the Reform and Innovation of Higher Vocational Education and Guiding Vocational Education Several Opinions on the Development of Education Science and Notice of the Ministry of Finance of the Ministry of Education on Supporting Higher Vocational Schools to Promote the Development Ability of Professional Services Industry. The three documents promote the progress of the upper levels, with both long-term goals and short-term plans that must be completed, making the development of higher vocational education enter the fast lane, thus arousing the attention of educators and actively responding countries.Call from home, vigorously develop vocational education, and finally, it can be found that after 2012, although the study of learning quality generally showed a downward trend, but generally maintained a certain number of publications, indicating that the evaluation of learning quality is 
104 The Current Situation and Prospect of Study Quality Evaluation Research in China in The Last 10 Years Wu Aixia, Zhou Ying, Tommy Tanu Wijaya

still a concern of researchers, but the attention has significantly decreased, so the study of learning quality evaluation should be further strengthened.

\section{Journal Distribution}

\section{Distribution of Published Journals}

The 108 selected papers are distributed in 84 journals, which shows that the study of learning quality evaluation has a wide range; on the other hand, although the number of journals is large, the number of journals is 1.2 , so it can be seen that the study of learning quality evaluation is still an area of less attention in the field of education research. Among them, the distribution of journals with more than or equal to 2 papers is shown in Table 1:

Table 1 Annual Number Distribution of Research Literature on Learning Quality Evaluation

\begin{tabular}{|c|c|c|c|}
\hline $\begin{array}{l}\text { Journal } \\
\text { Title } \\
\end{array}$ & Quantity & $\begin{array}{l}\text { Journal } \\
\text { Title }\end{array}$ & Quantity \\
\hline $\begin{array}{l}\text { Middle } \\
\text { School } \\
\text { Geograph } \\
\text { y } \\
\text { Teaching } \\
\text { Reference }\end{array}$ & 3 & $\begin{array}{l}\text { New } \\
\text { Course } \\
\text { Research } \\
\text { (Mid-term } \\
\text { Journal) }\end{array}$ & 2 \\
\hline $\begin{array}{l}\text { Cultural } \\
\text { and } \\
\text { educationa } \\
1 \text { materials }\end{array}$ & 3 & $\begin{array}{l}\text { Business } \\
\text { Report }\end{array}$ & 2 \\
\hline $\begin{array}{l}\text { Science } \\
\text { and } \\
\text { Education } \\
\text { Journal } \\
\text { (Mid-term } \\
\text { Journal) }\end{array}$ & 3 & $\begin{array}{l}\text { Journal of } \\
\text { Software } \\
\text { Vocational } \\
\text { and } \\
\text { Technical } \\
\text { College }\end{array}$ & 2 \\
\hline $\begin{array}{l}\text { Industry } \\
\text { and } \\
\text { Science } \\
\text { Forum }\end{array}$ & 3 & $\begin{array}{l}\text { The Age of } \\
\text { Think } \\
\text { Tanks }\end{array}$ & 2 \\
\hline $\begin{array}{l}\text { Journal of } \\
\text { Yan'an } \\
\text { Vocational }\end{array}$ & 3 & $\begin{array}{l}\text { Scientific } \\
\text { and } \\
\text { Technologi }\end{array}$ & 2 \\
\hline
\end{tabular}

\begin{tabular}{|c|c|c|c|}
\hline $\begin{array}{l}\text { and } \\
\text { Technical } \\
\text { College }\end{array}$ & & $\begin{array}{l}\text { cal } \\
\text { Information }\end{array}$ & \\
\hline $\begin{array}{l}\text { Software } \\
\text { Guide } \\
\text { (Education } \\
\text { al } \\
\text { Technolog } \\
\text { y) }\end{array}$ & 3 & $\begin{array}{l}\text { Information } \\
\text { Technology }\end{array}$ & 2 \\
\hline $\begin{array}{l}\text { Vocational } \\
\text { Education } \\
\text { Communi } \\
\text { cation }\end{array}$ & 2 & $\begin{array}{l}\text { Chinese } \\
\text { extramural } \\
\text { Education }\end{array}$ & 2 \\
\hline $\begin{array}{l}\text { animal } \\
\text { science } \\
\text { and } \\
\text { veterinary } \\
\text { medicine }\end{array}$ & 2 & Occupation & 2 \\
\hline $\begin{array}{l}\text { Contempo } \\
\text { rary } \\
\text { vocational } \\
\text { education }\end{array}$ & 2 & $\begin{array}{l}\text { Technology } \\
\text { entrepreneu } \\
\text { rs }\end{array}$ & 2 \\
\hline
\end{tabular}

Table 1 shows that these journals are mainly scientific and technical journals and professional journals, and other journals also pay attention to the study of learning quality evaluation, but the number of papers published by each journal is relatively small, indicating that the current research results of learning quality evaluation are relatively scattered.

\section{Proportion and distribution of core journals}

Among the 108 selected literatures, 11 were published in core journals with higher academic level, less than $14 \%$ of the total literature. It can be seen that the current research papers on learning quality evaluation in China are less published in core journals, and the specific distribution of journals is as follows (see Table 2).

Table 2 Distribution of Core Journals of Learning Quality Assessment Research 
105 The Current Situation and Prospect of Study Quality Evaluation Research in China in The Last 10 YearsWu Aixia, Zhou Ying, Tommy Tanu Wijaya

\begin{tabular}{|l|c|}
\hline Recognized kernel journals & $\begin{array}{c}\text { Number of } \\
\text { articles }\end{array}$ \\
\hline $\begin{array}{l}\text { Exploration of Higher } \\
\text { Education }\end{array}$ & 1 \\
\hline $\begin{array}{l}\text { animal science and veterinary } \\
\text { medicine }\end{array}$ & 2 \\
\hline $\begin{array}{l}\text { Middle School Geography } \\
\text { Teaching Reference }\end{array}$ & 1 \\
\hline $\begin{array}{l}\text { Vocational and Technical } \\
\text { Education }\end{array}$ & 1 \\
\hline Education and occupation & 1 \\
\hline Journal of Distance Education & 1 \\
\hline $\begin{array}{l}\text { Research on Modern Distance } \\
\text { Education }\end{array}$ & $\begin{array}{l}\text { Journal of Mathematical } \\
\text { Education }\end{array}$ \\
\hline
\end{tabular}

From this, we can see that the overall level of current research on learning quality evaluation is not high enough, and the degree of attention needs to be further strengthened, and the quality of research needs to be improved. How to play the guiding role of core journals in the theory and practice of learning quality evaluation deserves attention.

\section{Author information}

The author's academic literacy is the key factor affecting the research results. Statistical analysis of the author can reveal the distribution of the core authors and authors in this field. The author analyzes the author's situation of the study on the evaluation of learning quality in China from the perspective of the core author and the coauthor.

Price proposed a method to identify core authors (Ding Xuedong, 1992). The calculation method is: to indicate the minimum number of papers that core authors should publish, and to indicate the number of papers published by the authors with the most published papers. In this study sample, there are a total of 164 authors, and the published literature is shown in Table 3.

Table 3 Number of Publications and Distribution of Authors

\begin{tabular}{|l|c|c|c|c|}
\hline $\begin{array}{l}\text { Number } \\
\text { of articles } \\
\text { sent }\end{array}$ & $\begin{array}{c}\mathbf{4} \\
\text { articles }\end{array}$ & $\begin{array}{c}\mathbf{3} \\
\text { article } \\
\text { s }\end{array}$ & $\begin{array}{c}\mathbf{2} \\
\text { articles }\end{array}$ & $\begin{array}{c}\mathbf{1} \\
\text { article }\end{array}$ \\
\hline $\begin{array}{l}\text { Number } \\
\text { of } \\
\text { Authors }\end{array}$ & 1 & 0 & 12 & 151 \\
\hline $\begin{array}{l}\text { Proportio } \\
\mathrm{n}\end{array}$ & $0.61 \%$ & $0.00 \%$ & $7.32 \%$ & $\begin{array}{c}92.07 \\
\%\end{array}$ \\
\hline
\end{tabular}

Table 3 shows that 151 authors published 1 paper, 12 authors published 2 papers, 0 authors published 3 papers, and 1 author published 4 papers, so, Therefore, the authors who have published 2 or more papers are the core authors, and there are 13 core authors. The specific situation is as follows: the author who published 4 papers is Ye Ning, the author who published the most papers. The second is Tian Jin, Hong Ning, Huang Yingming, Quanzhiqiang, Wang Xuefang and other 12 authors, who published 2 papers respectively. $92.07 \%$ of the authors only published one paper, and only $7.84 \%$ of the authors published two papers and more than two papers, indicating that $92.07 \%$ of the authors did not have persistence in the study of this issue, and the researchers were relatively scattered.

Co-authorship is an important manifestation of scientific research cooperation (Chen Xinmin, 2014). The number and frequency of co-authorship reflect the degree of scientific research cooperation to a certain extent. See Table 4 for co-authored papers.

Table 4 Co-authorship of the authors 
106 The Current Situation and Prospect of Study Quality Evaluation Research in China in The Last 10 Years Wu Aixia, Zhou Ying, Tommy Tanu Wijaya

\begin{tabular}{|l|c|c|c|c|}
\hline & $\begin{array}{c}\text { single } \\
\text { author }\end{array}$ & $\begin{array}{c}\text { 2 co- } \\
\text { author } \\
\text { s }\end{array}$ & $\begin{array}{c}\text { 3 co- } \\
\text { author } \\
\text { s }\end{array}$ & $\begin{array}{c}4 \text { co- } \\
\text { author } \\
\text { s }\end{array}$ \\
\hline $\begin{array}{l}\text { Number } \\
\text { of Authors }\end{array}$ & 62 & 28 & 11 & 7 \\
\hline Proportion & $\begin{array}{c}57.41 \\
\%\end{array}$ & $\begin{array}{c}25.93 \\
\%\end{array}$ & $\begin{array}{c}10.19 \\
\%\end{array}$ & $6.48 \%$ \\
\hline
\end{tabular}

As can be seen from Table 4, from the number of co-authors, 62 of 108 papers were monographs, accounting for $57.41 \%$ of the total number of papers, There are 46 co-authors, accounting for $42.59 \%$ of the total number of papers. Among them, 28 co-authors, accounting for $25.93 \%$ of the total number of papers, 11 coauthors, accounting for $10.19 \%$ of the total number of papers, and 7 co-authors with 4 or more, accounting for $6.48 \%$ of the total number of papers. In terms of co-authorship frequency, 4 of 46 co-authored papers were co-authored twice by the same two people, accounting for $8 \%$ of the total number of co-authored papers. The coauthors were Wang Xiangcai and Wang Xueming, Ye Ning and Zhang Lijuan. The other papers were co-authored once by different two people, or once by three or four people, accounting for $92 \%$ of the total number of co-authored papers. The above data indicate that the research on the evaluation of learning quality in China is mainly conducted by individuals. Independent research is the main way, followed by unstable cooperation among authors, and the degree of cooperation needs to be improved.

\section{Analysis of paper impact}

The frequency of citation is an important index to measure the academic quality and influence of a work . The higher the frequency of citation, the greater the academic influence. In order to show the distribution of citation frequency of a paper more clearly, the number of citations will be divided into three grades on average after ranking from high to low. The distribution results of citation frequency of a paper are shown in Table 5.

Table 5 Frequency Distribution of Cited Papers

\begin{tabular}{|c|c|c|c|}
\hline $\begin{array}{c}\text { grad } \\
\mathbf{e}\end{array}$ & $\begin{array}{c}\text { frequencies of } \\
\text { citation }\end{array}$ & $\begin{array}{c}\text { number } \\
\text { of } \\
\text { papers }\end{array}$ & $\begin{array}{c}\text { proportio } \\
\text { n of total } \\
\text { papers }\end{array}$ \\
\hline 1 & $0-3$ & 86 & $79.63 \%$ \\
\hline 2 & $4-8$ & 14 & $12.96 \%$ \\
\hline 3 & $9-17$ & 8 & $7.41 \%$ \\
\hline
\end{tabular}

It can be found from Table 5 that 86 papers were cited from 0 to 3 times, accounting for $76.63 \%$ of the total number of papers; 14 papers were cited from 4 to 8 times, accounting for $12.96 \%$ of the total number of papers; 8 papers were cited from 9 to 17 times, accounting for $7.41 \%$ of the total number of papers.It indicates that the proportion of highly influential papers is not high.

The following lists the relevant information of the 8 papers cited in the third grade. The details are shown in Table 6.

Table 6 Situation of highly cited papers

\begin{tabular}{|l|c|c|c|}
\hline $\begin{array}{l}\text { freque } \\
\text { ncies } \\
\text { of } \\
\text { citatio } \\
\text { ns }\end{array}$ & Title & Aut & Journal \\
\hline 17 & $\begin{array}{c}\text { hor } \\
\text { learning quality in the integrated course } \\
\text { of science and practice in Higher } \\
\text { Vocational Education }\end{array}$ & $\begin{array}{c}\mathrm{He} \\
\text { Xin }\end{array}$ & Chemical times \\
\hline 14 & $\begin{array}{c}\text { Research on the evaluation system of } \\
\text { learning quality of diversified and open } \\
\text { vocational students based on AHP }\end{array}$ & $\begin{array}{c}\text { Zhan } \\
\text { Zhip } \\
\text { ing }\end{array}$ & $\begin{array}{c}\text { Journal of } \\
\text { Zhejiang } \\
\text { Normal } \\
\text { University }\end{array}$ \\
\hline 14 & $\begin{array}{c}\text { Che } \\
\text { Design of learning quality evaluation } \\
\text { system for vocational college students }\end{array}$ & $\begin{array}{c}\text { men } \\
\text { gxia } \\
\text { ng }\end{array}$ & $\begin{array}{c}\text { Education and } \\
\text { teaching forum }\end{array}$ \\
\hline
\end{tabular}


107 The Current Situation and Prospect of Study Quality Evaluation Research in China in The Last 10 Years Wu Aixia, Zhou Ying, Tommy Tanu Wijaya

\begin{tabular}{|c|c|c|c|}
\hline 14 & $\begin{array}{c}\text { Study on the evaluation system of } \\
\text { students' learning quality in Higher } \\
\text { Vocational Colleges }\end{array}$ & $\begin{array}{l}\text { Feng } \\
\text { Ning }\end{array}$ & $\begin{array}{c}\text { Education and } \\
\text { occupation }\end{array}$ \\
\hline 13 & $\begin{array}{c}\text { Evaluation report on learning quality of } \\
\text { mathematics problem-solving ability of } \\
\text { primary and secondary school students } \\
\text { in Beijing }\end{array}$ & $\begin{array}{c}\text { Du } \\
\text { Wen } \\
\text { ping }\end{array}$ & $\begin{array}{l}\text { Journal of } \\
\text { mathematics } \\
\text { education }\end{array}$ \\
\hline 13 & $\begin{array}{l}\text { Analysis of current situation of learning } \\
\text { quality evaluation of students in } \\
\text { Ningxia Vocational College }\end{array}$ & $\begin{array}{c}\text { Ye } \\
\text { Ning }\end{array}$ & $\begin{array}{c}\text { Journal of } \\
\text { Yan'an } \\
\text { vocational and } \\
\text { technical } \\
\end{array}$ \\
\hline 10 & $\begin{array}{l}\text { Study on the evaluation of learning } \\
\text { quality of vocational college students }\end{array}$ & $\begin{array}{c}\text { Zhan } \\
\text { g } \\
\text { Jian } \\
\text { ying }\end{array}$ & $\begin{array}{c}\text { Journal of } \\
\text { Hebei software } \\
\text { Polytechnic }\end{array}$ \\
\hline 9 & $\begin{array}{l}\text { Study on evaluation content of learning } \\
\text { quality of vocational college students }\end{array}$ & $\begin{array}{l}\text { Zhan } \\
\text { g } \\
\text { Jian } \\
\text { ying }\end{array}$ & $\begin{array}{c}\text { Journal of } \\
\text { Hebei Software } \\
\text { Vocational and } \\
\text { technical }\end{array}$ \\
\hline
\end{tabular}

As can be seen from Table 6, Hexin's published papers were cited 17 times, Zhang Zhiping, Chen Mengxiang, Feng Ning's published papers were cited 14 times, Du Wenping, Ye Ning's published papers were cited 11 times, Zhang Jianying's published papers were cited 10 times, these papers belong to the papers with high frequency of citation.

Among them, the most frequently cited is $\mathrm{He}$ Xin, Zhao Haoyu published the Study on Student Learning Quality Evaluation of Integrated Higher Vocational Practice Course in 2011, followed by Zhang Zhiping's Study on Diversified and Open Learning Quality Evaluation System of Higher Vocational Students Based on AHP Application published in 2011, and Zhang Mengxiang's Design of Student Learning Quality Evaluation System of Higher Vocational Colleges published in 2012.As well as Feng Ning's Inquiry into the Learning Quality Evaluation System of Higher Vocational College Students published in 2013, it shows that although these papers have received some attention from researchers, compared with other papers that have been cited a high number of times, these papers have received insufficient attention, so the study of learning quality evaluation needs to be strengthened.

\section{Research content analysis}

After thorough study of 108 literatures, comparative analysis and classification of the literature content, combined with topics, conclusions, and countermeasures and other contents, it is finally determined that the research content of learning quality evaluation is divided into four aspects: research paradigm analysis, research field analysis, research object analysis, and research topic analysis.

A paper may use more than one research method. In the analysis of this dimension, the main research paradigm of the paper is selected for analysis, and the statistical results are shown in Table 7.

Table 7 Research Paradigm Distribution Table

\begin{tabular}{|c|c|c|}
\hline \multicolumn{3}{|c|}{ Research Paradigm Distribution } \\
\hline $\begin{array}{c}\text { normal } \\
\text { form }\end{array}$ & $\begin{array}{c}\text { Speculative } \\
\text { category }\end{array}$ & $\begin{array}{c}\text { Empirical } \\
\text { Classification }\end{array}$ \\
\hline $\begin{array}{c}\text { Number of } \\
\text { articles }\end{array}$ & 91 & 17 \\
\hline Proportion & $84.26 \%$ & $15.74 \%$ \\
\hline
\end{tabular}

Statistical results are mainly divided into two categories: speculative (philosophical research) and empirical (scientific research). Of the 108 articles, 91 papers used the speculative research method, accounting for $84.26 \%$ of the total papers; 17 papers used the empirical research method, accounting for $15.74 \%$ of the total papers. This shows that there are few studies on the evaluation of learning quality by researchers at present, and the results are relatively concentrated in the theoretical aspects.

The research field can reflect the main object of the current study on the evaluation of learning 
108 The Current Situation and Prospect of Study Quality Evaluation Research in China in The Last 10 Years Wu Aixia, Zhou Ying, Tommy Tanu Wijaya

quality in China. According to the division of educational stage in China, this dimension classifies the research field into preschool education, primary education, secondary education and higher education. The specific results are shown in Table 8 .

Table 8. Research area distribution

\begin{tabular}{|c|c|c|}
\hline \multicolumn{3}{|c|}{ Distribution of research fields } \\
\hline $\begin{array}{l}\text { Domain } \\
\text { classificati } \\
\text { on }\end{array}$ & Field refinement & $\begin{array}{c}\text { Qua } \\
\text { ntit } \\
\text { y }\end{array}$ \\
\hline $\begin{array}{l}\text { preschool } \\
\text { education }\end{array}$ & Preschool education & 0 \\
\hline $\begin{array}{l}\text { primary } \\
\text { education }\end{array}$ & Primary School Education & 2 \\
\hline \multirow{3}{*}{$\begin{array}{l}\text { secondary } \\
\text { education }\end{array}$} & $\begin{array}{l}\text { Primary secondary education } \\
\text { (junior secondary) }\end{array}$ & 7 \\
\hline & $\begin{array}{l}\text { Secondary Vocational } \\
\text { Education (Secondary } \\
\text { Vocational) }\end{array}$ & 9 \\
\hline & $\begin{array}{l}\text { Advanced Secondary } \\
\text { Education (Senior High } \\
\text { School) }\end{array}$ & 2 \\
\hline \multirow{4}{*}{$\begin{array}{l}\text { Higher } \\
\text { Education }\end{array}$} & $\begin{array}{l}\text { Higher Vocational Education } \\
\text { (Higher Vocational } \\
\text { Education) }\end{array}$ & 66 \\
\hline & Undergraduate Education & 14 \\
\hline & Postgraduate Education & 1 \\
\hline & Other & 8 \\
\hline
\end{tabular}

From Table 8, we can see that the current research scope of learning quality evaluation in China is very wide, covering almost all stages of education. At the same time, it is unbalanced, for example, there are more research in higher vocational field than in other fields, 66 of 108 research papers are on Higher Vocational field, accounting for $60.55 \%$ of the total number of papers; while the related research in the field of infants is zero, and there is relatively few in primary and secondary education, indicating that there is a clear research field on learning quality evaluation by researchers at present. The unbalance of learning quality should be strengthened in pre-school education and primary education.

This dimension of research object analysis is further subdivided on the basis of research areas, the specific statistical results are shown in Table 9.

Table 9. Distribution Table of Subjects

\begin{tabular}{|l|c|c|}
\hline \multicolumn{3}{|c|}{ Research object classification } \\
\hline Research object & $\begin{array}{c}\text { Quant } \\
\text { ity }\end{array}$ & $\%$ \\
\hline Primary school students & 10 & $\begin{array}{c}9.26 \\
\%\end{array}$ \\
\hline $\begin{array}{l}\text { Secondary and higher } \\
\text { vocational students }\end{array}$ & 80 & $\begin{array}{c}74.07 \\
\%\end{array}$ \\
\hline $\begin{array}{l}\text { Undergraduate and } \\
\text { postgraduate }\end{array}$ & 15 & $\begin{array}{c}13.89 \\
\%\end{array}$ \\
\hline Other & 3 & $\begin{array}{c}2.78 \\
\%\end{array}$ \\
\hline
\end{tabular}

According to statistics, there are 80 papers in secondary and higher vocational schools, accounting for $74.07 \%$ of the total number of papers, which is the highest proportion of all the research objects. Secondly, there are 15 papers for undergraduate and postgraduate students, accounting for $13.89 \%$ of the total number of papers. Secondly, there are only 10 papers for primary and secondary school students, accounting for only $9.26 \%$ of the total number of papers. Therefore, the main research pairs of learning quality evaluation research in China are now. Such as students, especially students in secondary and higher vocational schools, but students in primary and secondary schools, undergraduates, postgraduates and other research are relatively few, indicating that current researchers pay less attention to the latter two objects, and the research 
109 The Current Situation and Prospect of Study Quality Evaluation Research in China in The Last 10 Years Wu Aixia, Zhou Ying, Tommy Tanu Wijaya

on the evaluation of learning quality of these students needs to be strengthened.

After in-depth study of the literature, the research content is divided into four topics: basic theoretical research, evaluation system construction, practice evaluation research, evaluation review research. Among them, the basic theoretical research mainly focuses on the characteristics, principles, current status, shortcomings and Countermeasures of the current evaluation of learning quality in China, such as Song Jian, Xue Hong, Guo Jun, etc. to analyze the motivation of geographic learning achievement and the difference of geographic learning quality under the stage of compulsory education, and to propose the effectiveness of developing students' Geographic literacy. Evaluation in the construction of evaluation system is mainly to build an index system for the evaluation of learning quality (Utami et al., 2019), and to carry out relevant research on the weight assignment of related indicators, such as $\mathrm{Ji}$ Yuedong combining the mode of engineering and personnel training, to build a quality evaluation system for the learning of Higher Vocational students, in order to achieve the goal of personnel training in Higher Vocational education, so as to improve the quality of Higher Vocational Schools And so on; the practical evaluation research mainly carries on the actual assessment of the students' learning quality, and carries out relevant research on the actual quantitative analysis of the research results, such as $\mathrm{Du}$ Wenping distributing relevant test papers to the students in grade 4 and 8 respectively, to measure the students' learning situation of math problem solving ability; the literature analysis is used to review the evaluation of learning qualityThere is only one research paper. At present, only Xiao Jianhui's Review of Research on Evaluation of Learning Quality of Work-Study Integration Course adopted this method (Xiao Jianhui, 2019). The specific statistical results are shown in Table 10.

Table 10 Study Topic Distribution Table

\begin{tabular}{|l|c|c|}
\hline \multicolumn{3}{|c|}{ Research topic classification } \\
\hline theme & $\begin{array}{c}\text { Quantiti } \\
\text { ty }\end{array}$ & $\%$ \\
\hline Basic theoretical research & 49 & $\begin{array}{c}45.37 \\
\%\end{array}$ \\
\hline $\begin{array}{l}\text { Construction of evaluation } \\
\text { system }\end{array}$ & 41 & $\begin{array}{c}37.96 \\
\%\end{array}$ \\
\hline $\begin{array}{l}\text { Research on practical } \\
\text { evaluation }\end{array}$ & 17 & $\begin{array}{c}15.74 \\
\%\end{array}$ \\
\hline Evaluation review research & 1 & $0.93 \%$ \\
\hline
\end{tabular}

Statistics show that there are 49 basic theoretical studies, accounting for $45.37 \%$ of the total number of papers; 41 evaluation systems, accounting for $37.96 \%$ of the total number of papers; 17 practical evaluation studies. It accounted for $15.74 \%$ of the total number of papers, while only one review study, only $0.93 \%$.From the number of papers published on different topics, we can analyze the main content of current research on learning quality evaluation in China. The above data show that the current theoretical research and evaluation system are the most focused content of all topics, while the practical evaluation and review research are relatively few, which is the content that needs to be further studied in the future.

\section{CONCLUSION}


Looking back on the research process of learning quality evaluation in China in the last 10 years, we can find the focus and areas that have not been paid attention to in the study of learning quality evaluation in China. Although great progress has been made in the study of learning quality evaluation in the field of Higher Vocational education, there are still many problems to be solved.

Firstly, the quality and quantity of research papers on learning quality evaluation in China need to be improved. Statistics show that there are only 11 studies on learning quality evaluation published in core journals in recent 10 years, and the research paradigm mainly focuses on speculative research. There are few empirical studies and lack of diverse research methods. There are many repetitive studies in the existing literature, especially in the field of secondary and higher vocational education.Most of the authors use speculative methods to explore the current situation and problems of learning quality evaluation based on their own experience, while empirical research methods are relatively few.

Secondly, in China, the researchers of learning quality evaluation mainly focus on individual independent research, but there are few cooperative research. The cooperation between researchers in different fields is quite rare. Researchers'research on students' learning quality is limited to a certain lesson or a certain chapter. They lack the continuous research on learning quality, that is, they lack long-term and lasting attention to a certain content.Some of the papers are just general, lacking in deep, high-quality and systematic research results, but also do not form a professional research team on a certain content, indicating that the current theoretical research and practical research on learning quality evaluation in China have not really been combined.

Finally, the research field of learning quality evaluation in China is extremely unbalanced. Researchers mainly study more in the field of Higher Vocational education, but relatively few in the field of early childhood, primary and secondary education, and the related research on middle school students'learning quality evaluation under the stage of compulsory education is quite scarce, which indicates that there are obvious research fields on learning quality evaluation by researchers at present.In view of the status and value of these research directions, the lack of relevant research will hinder the development of learning quality evaluation research in China.

\section{SUGGESTIONS}

First, strengthen the empirical research on the evaluation of learning quality. Although there are a large number of studies on the evaluation of learning quality at present, there are not many indepth, persuasive and high-quality research results. The reason is that the research methods of the evaluation of learning quality are not scientific enough, and the research results lack reliability and validity. Therefore, the empirical research methods should be strengthened in the future.Through investigation and experimentation, take out data and use real data to interpret and prove your research conclusions.

Second, broaden the research field of learning quality evaluation.Although the current research scope of learning quality evaluation in 
111 The Current Situation and Prospect of Study Quality Evaluation Research in China in The Last 10 Years Wu Aixia, Zhou Ying, Tommy Tanu Wijaya

China is very wide and covers almost all stages of education, there are few studies on pre-school education and primary and secondary education stages.Researchers mainly focus on the study of Higher Vocational education.The study of learning quality of primary and secondary school students in compulsory education stage has certain value.In-depth research can help teachers to grow better and improve the quality of education in primary and secondary schools. Therefore, the focus of research in the future should be properly placed on the pre-school and primary and secondary fields.

Third, pay attention to the diversity of learning quality evaluation. The current evaluation methods and subjects of learning quality evaluation are relatively simplified. Most of them use traditional examination evaluation and teachers'evaluation. Diversified, flexible evaluation methods and subjects play an important role in students' learning quality evaluation. Therefore, in future research, such asIn terms of evaluation methods, it is not only written tests, but also other evaluation methods, such as growth record bags, situational tests, behavioral observations, experimental tests and so on. In terms of evaluation subjects, in addition to teachers'evaluation, group mutual evaluation and students' self-evaluation can also be added.

Fourth, to achieve a combination of qualitative and quantitative evaluation of learning quality. In the current study of evaluation of learning quality, some key skills of students, such as computing ability, drawing ability, etc., are mainly evaluated by quantitative methods, while essential qualities are evaluated by qualitative methods, which are relatively single. Therefore, in the future research of evaluation of learning quality, qualitative and definite can be applied.Quantitative evaluation methods, such as core literacy evaluation, should be combined with qualitative evaluation of essential qualities and quantitative evaluation of key competencies. Portfolio method, interview method and other methods can be used for essential qualities, and test method for key competencies.

\section{REFERENCES}

Andini, D., Mulyani, N., Wijaya, T., \& Supriyati, D. (2018). Meningkatkan Kemampuan Komunikasi Matematis Dan Self Confidence Siswa Menggunakan Pendekatan PBL Berbantuan Geogebra. Jurnal Derivat: Jurnal Matematika Dan Pendidikan Matematika, 5(1), 82-93.

Arumugham, K. S. (2019). Teachers' understanding towards Portfolio assessment: A case study among Malaysian primary school teachers. Problems of Education in the 21st Century, 77(6), 695-704. https://doi.org/10.33225/pec/19.77.695

Cunhua, L., Ying, Z., Qunzhuang, O., \& Wijaya, T. T. (2019). MATHEMATICS COURSE DESIGN BASED ON SIX QUESTIONS COGNITIVE THEORY USING HAWGENT DYNAMIC MATHEMATIC. Journal On Education, 02(01), 36-44.

Fachrudin, A. D., Ekawati, R., Kohar, A. W., Widadah, S., Kusumawati, I. B., \& Setianingsih, R. (2019). Ancient China history-based task to support students' geometrical reasoning and mathematical literacy in learning Pythagoras. Journal of Physics: Conference Series, 1417(1). https://doi.org/10.1088/1742$6596 / 1417 / 1 / 012042$

Hutajulu, M., Wijaya, T. T., \& Hidayat, W. (2019). the Effect of Mathematical Disposition and Learning Motivation on Problem Solving: an Analysis. Infinity Journal, $\quad 8(2), \quad 229$. 
112 The Current Situation and Prospect of Study Quality Evaluation Research in China in The Last 10 Years Wu Aixia, Zhou Ying, Tommy Tanu Wijaya

https://doi.org/10.22460/infinity.v8i2.p229238

Kulsum, S. I., Hidayat, W., Wijaya, T. T., \& Kumala, J. (2019). ANALYSIS ON HIGH SCHOOL STUDENTS

MATHEMATICAL. Jurnal Cendekia: Jurnal Pendidikan Matematika, 03(02), 431436.

https://doi.org/https://doi.org/10.31004/cende kia.v3i2

Malinen, O. P., Savolainen, H., \& Xu, J. (2012). Beijing in-service teachers' self-efficacy and attitudes towards inclusive education. Teaching and Teacher Education, 28(4), 526-534.

https://doi.org/10.1016/j.tate.2011.12.004

Miguel-Revilla, D., Martínez-Ferreira, J. M., \& Sánchez-Agustí, M. (2020). Assessing the digital competence of educators in social studies: An analysis in initial teacher training using the TPACK-21 model. Australasian Journal of Educational Technology, 36(2), 112. https://doi.org/10.14742/ajet.5281

Pierce, R., Stacey, K., \& Barkatsas, A. (2007). A scale for monitoring students' attitudes to learning mathematics with technology. Computers and Education, 48(2), 285-300. https://doi.org/10.1016/j.compedu.2005.01.0 06

Sukaesih, S., Ridlo, S., \& Saptono, S. (2019). Development of biology teaching management textbooks based on competency and conservation to maximize Pedagogical and Content Knowledge (PCK) the prospective teachers. Journal of Physics: Conference Series, 1321(3). https://doi.org/10.1088/17426596/1321/3/032114

Tambychik, T., \& Meerah, T. S. M. (2010). Students' difficulties in mathematics problem-solving: What do they say? Procedia - Social and Behavioral Sciences, $8(5)$, 142-151. https://doi.org/10.1016/j.sbspro.2010.12.020

Utami, P., Pahlevi, F. R., Santoso, D., Fajaryati, N., Destiana, B., \& Ismail, M. E. (2019). Android-based applications on teaching skills based on TPACK analysis. IOP Conference Series: Materials Science and Engineering, 535(1). $\quad$ https://doi.org/10.1088/1757-
899X/535/1/012009

Wijaya, T. T., Dewi, N. S. S., Fauziah, I. R., \& Afrilianto, M. (2018). Analisis Kemampuan Pemahaman Matematis Siswa Kelas IX Pada Materi Bangun Ruang. UNION: Jurnal Ilmiah Pendidikan Matematika, 6(1), 19-28. https://doi.org/10.30738/.v6i1.2076

Wijaya, T. T., Ying, Z., \& Purnama, A. (2020). THE EMPIRICAL RESEARCH OF HAWGENT DYNAMIC MATHEMATICS TECHNOLOGY INTEGRATED INTO TEACHING. Journal Cendekia: Jurnal Pendidikan Matematika, 04(01), 144-150.

Yi, L., Ying, Z., \& Wijaya, T. T. (2019). The Trend of Mathematics Teaching Method Has Change From Fragments To Systematics. Journal Cendekia: Jurnal Pendidikan Matematika, 3(2), 471-480. https://doi.org/https://doi.org/10.31004/cende kia.v3i2.137 